\title{
Optimalisasi Kinerja Generator Induk Guna Menunjang Efisiensi Bahan Bakar Methane pada MV. Tangguh Hiri
}

\author{
Desamen Simatupang ${ }^{1}$, Imam Fahcruddin ${ }^{2}$, Faza Rais Purnomo ${ }^{3}$ \\ ${ }^{1,2,3}$ Prodi Teknika \\ Sekolah Tinggi Ilmu Pelayaran, Jakarta \\ Jl. Marunda Makmur No. 1 Cilincing, Jakarta Utara. Jakarta 14150
}

\begin{abstract}
Abstrak
Kebutuhan bahan bakar alternatif merupakan solusi yang penting guna menunjang efisiensi industri pelayaran. Methane merupakan salah satu bahan bakar generator induk sebagai mesin utama kapal niaga. Terganggunya operasional generator induk dapat mengakibatkan kendala dalam operasional kapal. Masalah yang sering terjadi adalah tingginya suhu gas buang pada saat generator induk menggunakan methane sebagai bahan bakar utama dan penurunan suhu dan tekanan gas methane pada saat memasuki ruang unit gas. Tujuan penelitian ini yaitu mengetahui penyebab tingginya suhu gas buang generator induk saat menggunakan bahan bakar methane dan mengetahui penyebab rendahnya suhu dan tekanan gas methane saat memasuki ruang unit gas pada ruang mesin. Metode yang digunakan dalam penelitian ini adalah deskriptif kuallitatif. Dari hasil penelitian diperoleh kesimpulan bahwa terjadinya kenaikan suhu gas buang pada generator induk disebabkan oleh kerusakan bagian-bagian pada generator induk yang bertugas untuk mengolah bahan bakar methane sebelum masuk ke dalam ruang pembakaran dan kerusakan pada Cylinder Control Module disebabkan karena tidak stabilnya listrik kapal sehingga sering terjadi keterlambatan pengiriman data spesifik tentang generator induk oleh Cylinder Control Module, serta rendahnya kualitas media penghantar listrik dalam hal ini kabel. Rendahnya suhu dan tekanan bahan bakar methane disebabkan oleh tidak maksimalnya penggunaan Low Duty Compressor yang yang bertugas untuk menyuplai dan menekan methane sebelum masuk ke dalam sistem bahan bakar methane di dalam kamar mesin..
\end{abstract}

Copyright $\odot$ 2020, Prosiding Seminar Pelayaran dan Riset Terapan

Kata Kunci: optimalisasi, generator, methane

Permalink/DOI : https://doi.org/10.36101/pcsa.v2i1.137

\section{PENDAHULAN}

Dalam memasuki era perdagangan bebas, kapal adalah merupakan transportasi angkutan yang menjadi pilihan utama bagi pengguna jasa sabagai sarana bisnis dalam kapasitas besar dibanding sarana transportasi lain. Peranan transportasi laut dalam perkembangan perekonomian suatu negara sangatlah besar, transportasi laut sebagai sarana export import suatu negara merupakan pendorong kegiatan perdagangan. Oleh sebab itu perkembangan dunia pelayaran harus ditingkatkan sesuai dengan perkembangan.

Kebutuhan akan adanya bahan bakar alternatif merupakan suatu pemikiran penting guna menunjang efisiensi industri pelayaran. Liquified natural gas (LNG) yang merupakan bentuk cair dari gas methane, adalah bahan bakar fosil terbersih, menghasilkan kurang dari setengah karbon dioksida yang dihasilkan oleh batu bara.
Oleh karena itu, penggunaan gas methane pada mesin penggerak kapal menjadi pilihan bagi perusahaan pelayaran guna memenuhi peraturan International Maritime Organization (IMO) dan Marine Pollution (MARPOL) mengenai emisi gas buang. Hal ini merupakan langkah yang hemat dan efektif, dikarenakan selain dapat menggantikan bakan bakar minyak yang persediaannya makin terbatas, bahan bakar ini juga berasal dari penguapan muatan kapal itu sendiri untuk kebutuhan energi sebagai sumber tenaga mesin penggerak di atas kapal, sehingga tidak ada energi yang terbuang secara percuma.

Pentingnya peranan generator induk sebagai mesin utama pengguna bahan bakar methane sekaligus penyedia sumber tenaga di atas kapal, merupakan salah satu faktor yang harus di ketahui dan ditingkatkan peranannya guna menunjang pengoperasian kapal.

Ketika peneliti melakukan pengamatan, terganggunya operasional generator induk 
merupakan hal yang sering terjadi. Salah satunya adalah terjadinya trip atau kegagalan proses peralihan penggunaan bahan bakar dari diesel ke bahan bakar methane pada generator induk. Perbedaan suhu yang besar setelah proses pemuatan cargo mengakibatkan tingginya tingkat penguapan LNG sehingga menghasilkan vapour methane. Akumulasi dari vapour methane tersebut mengakibatkan tingginya tekanan pada tanki cargo.

Ada dua cara dalam menangani hal tersebut, yang pertama adalah membakar vapour methane melalui Gas Combustion Unit (GCU) dan yang kedua adalah menggunakan vapour methane sebagai bahan bakar generator induk. Namun penggunaan vapour methane dibatasi hanya pada saat kapal sedang dalam posisi on voyage atau pada saat kapal sedang dalam anchorage. Hal ini dikarenakan beban atau load generator harus dalam keadaan yang stabil dan tidak boleh dibawah $15 \%$. Proses peralihan penggunaan bahan bakar dari diesel ke bahan bakar methane sering mengalami kegagalan dan mengganggu operasional generator induk.

Salah satu faktor penyebab trip pada generator induk di atas adalah rendahnya suhu dan/atau tekanan bahan bakar methane pada saat memasuki area kamar mesin. Rendahnya suhu dan tekanan bahan bakar methane dapat diakibatkan berbagai masalah mulai dari kesalahan pengaturan hingga kerusakan pada komponen sistem bahan bakar methane. Sistem pembakaran bahan bakar methane pada generator induk bersifat sangat sensitif terhadap perubahan suhu dan tekanan bahan bakar methane, sehingga perbedaan suhu dan/atau tekanan pada bahan bakar methane sedikit saja dapat mengganggu operasional generator induk.

Kegagalan penggunaan bahan bakar methane tidak hanya terjadi saat peralihan dari penggunaan bahan bakar diesel ke bahan bakar methane, namun juga saat generator telah menggunakan bahan bakar methane. Menurunnya kualitas pembakaran pada generator induk menyebabkan tingginya suhu gas buang pada tiap silinder, dan sebagai salah satu fitur keamanan, generator induk akan kembali menggunakan bahan bakar diesel. Tingginya suhu gas buang tersebut disebabkan oleh menurunnya kualitas bahan bakar methane yang dapat bersumber dari kurang optimalnya kondisi komponen permesinan terkait penyediaan bahan bakar methane.

Terganggunya operasional generator induk tidak hanya dapat disebabkan oleh buruknya kondisi bahan methane dan/atau rusaknya komponen permesinan terkait, namun juga dapat disebabkan kesalahan pengoperasian permesinan.
Dikarenakan panjang dan rumitnya proes penyediaan bahan bakar methane, tidak jarang kurangnya pemahaman dan kesalahan yang dilakukan masinis mengakibatkan terganggunya proses penyediaan bahan bakar methane tersebut.

Permasalahan-permasalahan mengakibatkan terganggunya operasional generator induk sehingga generator induk tidak dapat menggunakan bahan bakar methane dan harus menggunakan bahan bakar diesel, yang mana mengakibatkan bertambahnya biaya operasional kapal. Terdapat empat generator induk yang terdiri dari dua unit $12 \mathrm{~V}$ dengan daya keluaran $11400 \mathrm{~kW}$ dan dua unit 9L dengan daya keluaran $8550 \mathrm{~kW}$. Saat menggunakan diesel sebagai bahan bakar utamanya, satu unit generator induk menggunakan $189 \mathrm{gr} / \mathrm{kWh}$ pada kondisi $100 \%$ MCR (Maximum Continuous Rating), yang dapat dikalkulasikan bahwa untuk satu generator induk $12 \mathrm{~V}$ menggunakan 2.15 ton bahan bakar diesel per jamnya dan satu generator induk 9L menggunakan 1.6 ton bahan bakar diesel per jamnya. Dengan harga bahan bakar diesel yang mencapai 1.2 euro per liter atau setara dengan 19400 rupiah per liter, kerugian yang terjadi saat menggunakan bahan bakar diesel sebagai bahan bakar utama generator induk dapat mencapai

Dengan adanya kejadian ini maka diperlukan suatu cara dalam mengoptimalkan kinerja generator induk sehingga efisiensi bahan bakar di atas kapal dapat berlangsung secara maksimal.

Ditinjau dari segi pengoperasian, perawatan serta perbaikan pada sistem penyediaan bahan bakar methane terlihat sangat rumit, dan yang menjadi masalah pokok adalah tidak stabilnya suhu dan tekanan dari gas methane tersebut yang menyebabkan berbagai macam masalah pada generator induk.

Dari masalah pokok di atas didapat rincian masalah sebagai berikut :

1. Tingginya suhu gas buang tiap silinder pada generator induk

2. Rendahnya suhu dan tekanan gas methane pada area kamar mesin

3. Terjadinya trip atau kegagalan proses peralihan penggunaan bahan bakar dari diesel ke bahan bakar methane pada generator induk

4. Kurangnya pemahaman dalam hal penyediaan bahan bakar methane dari proses evaporasi muatan sampai ke area kamar mesin.

Penelitian ini mengkaji tentang:

1. Apa penyebab tingginya suhu gas buang pada saat generator induk menggunakan methane sebagai bahan bakar utama?

2. Apa penyebab dari penurunan suhu dan tekanan gas methane pada saat memasuki ruang unit gas? 
Adapun tujuan dari penelitian ini yaitu:

1. Untuk mengetahui penyebab tingginya suhu gas buang generator induk saat menggunakan bahan bakar methane.

2. Untuk mengetahui penyebab rendahnya suhu dan tekanan gas methane saat memasuki ruang unit gas pada ruang mesin.

\section{METODE}

Metode Pendekatan yang digunakan dalam penelitian ini adalah metode pendekatan deskriptif kualitatif. Dalam memperoleh data peneliti menggunakan teknik pengumpulan data berupa observasi. Observasi adalah pengumpulan data berupa informasi berdasarkan pengamatan langsung oleh peneliti di MV. Tangguh Hiri.

\section{HASIL DAN PEMBAHASAN \\ 1. Tingginya Suhu Gas Buang Tiap Silinder Pada Generator Induk}

Masalah serius yang sering terjadi adalah tingginya suhu gas buang yang terkandung dalam gas buang pada generator induk. Kejadian tersebut terjadi pada tanggal 23 Februari 2017 jam 16.30 waktu setempat ditengah perjalanan pulang menuju Bintuni, Papua setelah melakukan proses bongkar muat (discharge) di Meksiko. Hal ini terjadi dikarenakan oleh buruknya proses pembakaran yang terjadi di dalam silinder, ketidaknormalan tappet clearance, rendahnya kualitas bahan bakar methane, serta rusaknya katup pemasukan gas utama atau GAV.

Normalnya, untuk kasus buruknya pembakaran di dalam silinder, ketidaksesuaian rasio antara udara pembakaran dan bahan bakar methane merupakan penyebab utama, namun ketidaknormalan tappet clearance juga merupakan masalah yang saling terkait dengan buruknya pembakaran di dalam silinder. Normalnya tenaga torsi yang diberikan untuk mengencangkan baut yoke sebagai tindak lanjut menentukan tappet clearance adalah $400 \mathrm{Nm}$.

Namun seiring waktu, terjadinya deposit karbon di sekitar mekanisme katup dan juga getaran yang terjadi pada generator induk menyebabkan terjadinya perubahan yang signifikan pada tingkat kekencangan baut yoke yang merupakan sumber masalah dari perubahan tappet clearance. Masalah tersebut juga dapat mengakibatkan rusaknya keseimbangan antara rasio udara pembakaran dengan gas methane. Ketidakseimbangan rasio udara pembakaran dengan gas methane, dapat ditemukan dengan melihat dan memeriksa suhu gas buang dan tekanan udara masuk dari Engine Control Console. Sehingga tindakan perbaikan seperti pengencangan baut yoke, pemeriksaan mekanisme katup, pemeriksaan kondisi waste gate valve, dan juga pengecekan kebocoran flexible joint dari gas buang tiap silinder dapat dilakukan.

Namun masalah-masalah diatas bukanlah penyebab utama dari tingginya suhu gas buang. Normalnya, tingginya suhu gas buang pada tiap silinder diakibatkan buruknya pemasukan bahan bakar methane pada ruang pembakaran. Hal ini disebabkan oleh kurang presisinya Gas Admission Valve (GAV) yang memiliki fungsi untuk mengatur pemasukan gas methane pada ruang pembakaran. GAV merupakan solenoid valve yang pada umumnya dikendalikan oleh sinyal energi listrik berupa sinyal yang dikirim oleh Cylinder Control Module (CCM). GAV akan membuka atau menutup sudu-sudu di dalamnya guna mengatur jumlah injeksi gas methane ke ruang pembakaran. Kerusakan pada GAV normalnya disebabkan karena tingginya suhu yang dihasilkan akibat pembakaran gas methane. Suhu gas buang yang dapat mencapai $600^{\circ} \mathrm{C}$, mengakibatkan kelonggaran pada sudu-sudu GAV akibat pemuaian. Sehingga pengaturan injeksi gas methane pada ruang pembakaran tidak dapat berjalan dengan semestinya.

Kerusakan pada GAV juga dapat disebabkan oleh karena tidak stabilnya suplai energi listrik dari Cylinder Control Module (CCM) kepada GAV. Main Control Module (MCM) sebagai pusat pengendalian yang menggunakan data-data parameter mesin akan meneruskan sinyal pengendalian bukaan katup pada CCM yang natinya akan diteruskan ke GAV. Permasalahan timbul saat sinyal yang diteruskan oleh CCM tidak sesuai dengan yang telah dikrimkan oleh MCM. Ketidaksesuaian ini disebabkan buruknya kualitas kabel pada GAV yang bertindak sebagai perantara pengiriman sinyal dan suplai listrik. Penyebab lain adalah buruknya sistem grounding pada generator induk sehingga menyebabkan kebocoran arus. Buruknya sistem grounding normalnya disebabkan oleh terjadinya deposit debu atau kotoran lainnya. Pada dasarnya, masalah-masalah yang terjadi diatas disebabkan ketidakstabilan kondisi methane serta kondisi permesinan maupun bagian-bagiannya.

\section{Rendahnya Suhu dan Tekanan Bahan Bakar Methane pada Area Kamar Mesin}

Dalam deskripsi data ini akan diuraikan mengenai kejadian yang menyangkut kesalahan yang terjadi pada proses pengolahan bahan bakar methane yaitu terjadinya kesalahan penggunaan GCU yang berlebih, menyebabkan berkurangnya tekanan dan suhu dari gas methane secara drastis yang memicu terjadinya trip condition pada generator induk. Kejadian tersebut terjadi pada 
tanggal 16 Februari 2017 jam 13.15 waktu setempat setelah melakukan proses pemuatan (loading) LNG di pelabuhan PT. BP (British Petroleum) untuk proyek TANGGUH LNG Bintuni. Normalnya, setelah proses pemuatan masinis muatan akan menyalakan GCU guna mengurangi tekanan di dalam tangki muatan yang diakibatkan oleh proses evaporasi muatan. Beberapa waktu setelah proses pemuatan baru saja berakhir, tingkat evaporasi LNG sangat tinggi akibat perbedaan suhu yang signifikan antara tangki dan juga muatan yang dimuat dari terminal LNG. GCU bertugas membakar gas methane sehingga tekanan di dalam tangki muatan berkurang, yang awalnya bisa mencapai 120 KpaA turun ke titik normal (berkisar 110-112 KpaA).

Selain penyebab tersebut, kurangnya komunikasi antara masinis muatan dan para masinis di ruang mesin juga dapat memicu berkurangnya tekanan dan suhu untuk generator induk secara drastic, yang normalnya mencapai $420 \mathrm{Kpa}$ untuk tekanan dan $35^{\circ} \mathrm{C}$ untuk suhu. Penyebab utama dari hal ini adalah pemberian aliran menuju GCU secara berlebih oleh masinis muatan. Penurunan suhu dan tekanan yang signifikan dapat memicu sistem proteksi pada generator induk untuk mengirim sinyal ke katup pemasukan gas utama dalam ruang unit katup gas, sehingga generator induk akan masuk ke mode trip condition. Trip condition ini bertujuan untuk menghindari terjadinya kerusakan pada mekanisme katup di dalam cylinder head, dikarenakan rendahnya tekanan dan suhu bahan bakar methane yang dapat memicu terjadinya detonasi yang dapat menyebabkan keretakan pada mekanisme katup. Masalah-masalah diatas disebabkan karena terjadinya perbedaan keperluan yang saling bertolak belakang antara generator induk sebagai penghasil listrik utama diatas kapal yang normalnya harus menyediakan daya listrik yang besar untuk sistem penggerak kapal, serta GCU yang bertugas untuk mengatur tekanan di dalam tangki muatan.

Adapun masalah lainnya yang dapat mengakibatkan terjadinya penurunan suhu dan tekanan dari bahan bakar methane tersebut, yaitu kurangnya penggunaan Gas Heater. Gas Heater memiliki fungsi untuk meningkatkan suhu dari bahan bakar methane dengan menggunakan uap bertekanan $1 \mathrm{Mpa}$ dari ketel bantu sebagai media pemanas. Uap tersebut akan masuk ke bagian shell sementara bahan bakar methane akan berada di dalam bagian tube dari Gas Heater tersebut. Normalnya, Gas Heater hanya digunakan jika suhu muatan yang diberikan oleh terminal mencapai tingkat yang sangat dingin yaitu mencapai $-161^{\circ} \mathrm{C}$ atau biasa disebut Cold Cargo. Suhu muatan yang diberikan oleh terminal normalnya berkisar $157^{\circ} \mathrm{C}-159^{\circ} \mathrm{C}$ dibawah nol, dan kondisi muatan seperti ini disebut sebagai Hot Cargo. Namun, kondisi Hot Cargo tidak menjamin cocoknya suhu dan tekanan bahan bakar methane yang akan disuplai menuju kamar mesin. Dikarenakan tidak stabilnya sifat dari LNG itu sendiri, serta tidak memungkinkannya pengaturan secara instan pada Pre-cooler.

Selain dua masalah utama penyebab terjadinya penurunan suhu dan tekanan bahan bakar methane di atas, masih banyak masalahmasalah ataupun penyebab dari turunnya suhu dan tekanan bahan bakar methane. Di bawah ini penulis akan memaparkan kembali penyebab sensor suhu dan tekanan bahan bakar methane mendeteksi alarm low maupun low-low selain penyebab-penyebab diatas, yaitu:

a. Terjadinya kebocoran uap di dalam Gas Heater

b. No. 1 dan No. 2 Boiler Trip

c. Rusaknya katup pengendali otomatis pada Precooler

d. Rendahnya suhu dan tekanan muatan yang diberikan terminal

e. Rusaknya sensor suhu dan tekanan bahan bakar methane

f. Terjadinya keabnormalan di dalam ruang unit katup gas

g. Rusaknya pengendali aliran menuju burner GCU

h. Terjadinya trip condition pada Low Duty Compressor

Di dalam analisa ini akan dititikberatkan pada bagaimana proses terjadinya penurunan suhu dan tekanan bahan bakar methane serta proses terjadinya kenaikan suhu gas buang pada tiap silinder generator induk, yang berujung pada ketidakefisienan dan tidak optimalnya penggunaan bahan bakar methane di atas MV. Tangguh Hiri. Adapun tujuan analisis data ini adalah untuk menganalisis masalah sehingga solusi dari masalah tersebut dapat ditemukan.

1. Tingginya Suhu Gas Buang Tiap Silinder Pada Generator Induk

Setelah dibahas dan dianalisis sesuai dengan data yang ada, maka pada bagian ini akan dijelaskan bagaimana perbandingan antara kondisi yang normal dan tidak normal dan dimana letak kondisi yang tidak normal didalam sistem penyuplaian bahan bakar methane yang menyebabkan terjadinya kenaikan suhu gas buang dari tiap silinder generator induk.

Ketidaknormalan ini diketahui dari indikator pada Wartsila Operator Interface System (W.O.I.S), yang menunjukan adanya 
ketidaknormalan pada bagian suhu gas buang generator induk. Suhu dari gas buang generator induk mencapai titik yang terlalu tinggi yaitu $540^{\circ} \mathrm{C}$. Hal ini mengaktifkan alarm sebagai indikasi adanya masalah pada sistem bahan bakar. Masalah ini terus menuju kearah yang lebih buruk, dimana suhu gas buang dari generator induk terus naik dan mencapai titik $600^{\circ} \mathrm{C}$. Hal ini mengaktifkan relay module MCM yang membuat generator induk masuk ke mode trip condition. Sehingga penyediaan tenaga utama sistem propulsi pada MV. Tangguh Hiri terganggu.

a. Kondisi normal yang terjadi pada pada gas admission system

Proses normal yang terjadi pada sistem ini adalah bahan bakar methane yang telah melewati ruang Gas Valve Unit (GVU) untuk disesuaikan suhu dan tekanannya, akan didistribusikan menuju tiap-tiap silinder generator induk. Pada tiap-tiap silinder generator induk terdapat Gas Admission Valve (GAV) yang akan menyesuaikan jumlah bahan bakar methane yang akan disuplai secara spesifik sesuai kondisi pembakaran pada tiap-tiap silinder. Pada proses yang normal, GAV akan membuka sesuai dengan sinyal bukaan yang dikirimkan oleh CCM. Bukaan GAV pada tiap silinder akan berbeda-beda dikarenakan berbedanya kondisi pembakaran pada tiap-tiap silinder dan akan menghasilkan pembakaran yang sempurna dan suhu gas buang yang normal.

b. Kondisi meningkatnya suhu gas buang generator induk

Pada prinsipnya, penggunaan bahan bakar methane Tingginya suhu gas buang terjadi saat kapal mengganti mode bahan bakar solar ke mode bahan bakar gas (Gas Mode). Umumnya, penggantian mode bahan bakar ini dilakukan saat kapal selesai melakukan maneuvering dan akan memasuki kondisi full away setelah kegiatan bongkar muat selesai.

Pada kondisi tersebut, suhu gas buang akan naik sebagai hasil dari penggunaan bahan bakar methane. Kenaikan suhu gas buang tidak akan berlangsung lama karena sistem akan segera menyesuaikan dan pembakaran akan normal kembali. Main Control Module akan segera mengatur rasio udara dan bahan bakar yang baru dan menurunkan suhu gas buang pada tingkat yang normal yaitu $490^{\circ} \mathrm{C}-510^{\circ} \mathrm{C}$. Namun, saat suhu gas buang tidak kunjung turun ke tingkat yang normal dan melewati batas deviasi dari nilai mean suhu gas buang antar silinder, sistem proteksi generator induk akan mengganti mode bahan bakar kembali ke mode bahan bakar solar (trip condition).

Setelah diamati melalui Wartsila Engine Control System (WECS), ditemukan ketidaksesuaian bukaan pada GAV di salah satu silinder generator induk. Normalnya, sinyal bukaan (SV) dan bukaan GAV (PV) akan tidak jauh berbeda. Namun, saat masalah ini terjadi, dapat dilihat pada gambar dibawah bahwa sinyal bukaan menunjukkan nilai 109 dan bukaan GAV hanya pada nilai 88 .

Permasalahan ini juga dapat diakibatkan oleh ketidaksesuaian pada waste gate yang berfungsi mengatur suplai udara dengan mengontrol kecepatan turbocharger. Normalnya, waste gate akan bekerja secara otomatis setelah menerima sinyal dari Main Control Module (MCM). Namun, karena kerusakan pada sensor salah satu sistem kontrol, waste gate tidak dapat membuka dan menutup sebagai mana mestinya sehingga rasio udara yang baik tidak dapat dicapai dan menimbulkan tingginya suhu gas buang akibat dari tidak sempurnanya pembakaran di dalam silinder.

2. Rendahnya Suhu dan Tekanan Bahan Bakar Methane pada Area Kamar Mesin

Bahan bakar methane adalah gas methane hasil proses evaporasi muatan kapal LNG. Untuk penyesuaian suhu dan tekanan bahan bakar methane, vapour gas akan masuk ke ruang katup unit gas (GVU). Pada ruang ini proses penyaringan, pengaturan, serta proses pemeriksaan bahan bakar methane akan dilakukan. Pada ruang ini juga proses purging bahan bakar methane dengan menggunakan nitrogen dapat dilakukan. Pada proses yang normal, sistem ini berjalan dengan menjaga tekanan bahan bakar methane pada $420-550 \mathrm{kPa}$, dan suhu pada $35-40^{\circ} \mathrm{C}$. Dikarenakan penggunaan GCU pada waktu yang bersamaan, penurunan suhu dan tekanan bahan bakar methane secara tiba-tiba akhirnya terjadi. Hal ini dideteksi oleh sistem pengaman generator induk sehingga, sebagai tindak perlindungan pada generator induk, relay module akan mengaktifkan mekanisme trip condition pada generator induk demi mencegah terjadinya kerusakan.

a. Kondisi normal yang terjadi pada fuel gas system

Proses normal yang terjadi pada sistem ini adalah gas methane yang digunakan sebagai bahan bakar berasal dari proses evaporasi muatan LNG yang memiliki suhu $+160^{\circ} \mathrm{C}$ di bawah nol, serta memiliki kandungan methane $+96 \%$ yang kemudian akan terkumpul pada bagian tertentu dalam tangki muatan berupa Gas Dome, untuk diproses lebih lanjut dalam sistem penyuplaian bahan bakar methane. Setelah terkumpul pada Gas Dome, gas methane tersebut dihisap oleh dua buah compressor berkapasitas rendah yang disebut dengan Low Duty Compressor, didalam 


\section{http://ejournal.stipjakarta.ac.id/index.php/pcsa}

compressor tersebut tekanan methane akan diatur sedemikian rupa antara $178-650 \mathrm{kPa}$ (ditentukan berdasarkan tingkat kandungan methane dalam vapour). Selain perubahan tekanan, perubahan suhu antara $30,5-66,7^{\circ} \mathrm{C}$ juga terjadi.

Pada proses normal, hanya satu compressor yang dioperasikan sebagi pengatur tekanan methane sekaligus sebagai pengatur suhu dan flow rate dari bahan bakar methane tersebut. Sementara satu compressor lainnya dalam posisi standby dan siap dipakai guna mengantisipasi terjadinya trip condition pada compressor yang sedang dioperasikan (running compressor). Hal ini dilakukan demi memastikan stabilnya proses penyuplaian bahan bakar methane ke dalam kamar mesin serta mencegah kenaikan tekanan tangki muatan secara tiba-tiba.

Setelah melalui Low Duty Compressor, pengaturan bahan bakar methane selanjutnya akan diteruskan ke dalam kamar mesin, yaitu ruang Gas Valve Unit (GVU). Proses ini telah dijelaskan pada bagian deskripsi data sebelumnya pada permasalahan menurunnya tekanan dan suhu bahan bakar methane. Pada ruang GVU, terjadi suatu pengaturan tekanan dan suhu bahan bakar methane berdasarkan kondisi generator induk. Data-data tentang kondisi generator induk tersebut diperoleh dari Integrated Automatic System (IAS), yang telah terintegrasi dengan sistem kontrol generator induk itu sendiri. Sementara pressure regulating valve yang bertugas sebagai pengatur tekanan dan injeksi utama dalam ruang tersebut diatur oleh sistem kontrol utama generator induk itu sendiri, yaitu Wartsila Engine Control System (WECS) 8000.

Selama proses penyalaan dan pemberhentian generator induk, kendali berurut dari katup keamanan dan katup ventilasi, berkomunikasi antara WECS dan Unit Control Panel (UCP). Komunikasi ini juga mencangkup pengecekan kebocoran katup, dilaksanakan setiap proses penyalaan generator induk dan menggunakan nitrogen sebagai gas perantara. Tekanan gas suplai yang bersangkutan akan dihitung dan diperiksa dalam MCM yang bertindak sebagai inti dari WECS 8000. Setelah itu akan dikirim sinyal referensi tentang tekanan gas berdasarkan beban generator induk. Sinyal elektrik sesudah itu akan dikirim kepada GAV. Tekanan gas yang sebenarnya, akan dihitung pada mesin dan dibandingkan dengan tekanan referensi. Jika perbedaan yang didapat terlalu besar, alarm akan menyala. Jika perbedaan semakin meningkat, katup keamanan dalam ruang GVU akan sesegera mungkin memotong suplai gas ke dalam mesin. Jumlah gas yang diinjeksikan ke dalam tiap silinder akan dikendalikan oleh GAV yang terpasang di tiap silinder, dan dikendalikan oleh CCM. Jumlah gas yang diinjeksi tergantung pada tekanan gas suplai dan waktu durasi dari pembukaan GAV.

Proses normal dari sistem penyuplaian bahan bakar methane pada ruang GVU dapat

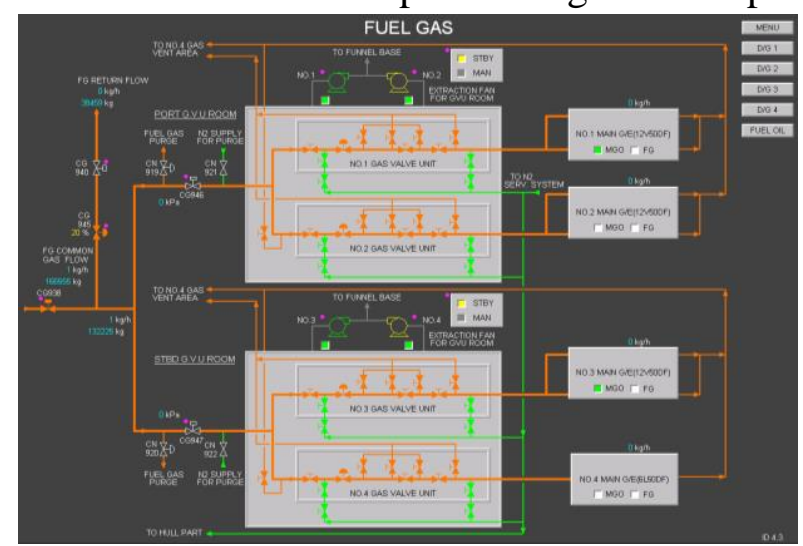

dilihat pada skema IAS dibawah ini :

Gambar 1. Diagram Sistem Bahan Bakar Methane

di GVU (Hyundai Heavy Industry, 2009: 207)

Selain skema diatas, penulis juga melampirkan daftar checklist yang juga dapat digunakan sebagai persyaratan yang harus dipenuhi dalam penggunaan generator induk sesuai dengan anjuran dari pihak maker:

Tabel 1. Alarm Penggunaan Generator Induk

\begin{tabular}{|l|c|c|c|}
\hline High MFI demand offset & CX9011A & $>+20 \%$ & $30 \mathrm{sec}$ \\
\hline Low MFI demand offset & CX9101B & $<-20 \%$ & $30 \mathrm{sec}$ \\
\hline $\begin{array}{l}\text { High gas pressure deviation from } \\
\text { reference }\end{array}$ & PT901 & $30 \mathrm{kPa}$ & $10 \mathrm{sec}$ \\
\hline Low gas valve unit inlet gas pressure & P003 & $400 \mathrm{kPa}$ & $3 \mathrm{sec}$ \\
\hline High gas valve unit inlet gas pressure & P003 & $800 \mathrm{kPa}$ & $3 \mathrm{sec}$ \\
\hline High gas valve unit inlet gas temperature & T001 & $50{ }^{\circ} \mathrm{C}$ & \\
\hline $\begin{array}{l}\text { Engine load over max. transfer level } \\
\text { (active only during transfer) }\end{array}$ & UA793 & $80 \%$ & $0 \mathrm{sec}$ \\
\hline $\begin{array}{l}\text { CAN communication failure } \\
\text { CCM/MCM, ACQ }\end{array}$ & NS810\#/811\# & true & $3 \mathrm{sec}$ \\
\hline
\end{tabular}

Tabel 2. Alarm Penggunaan Generator Induk

\begin{tabular}{|l|c|c|r|}
\hline High lube oil temperature, engine inlet & TE201 & $70{ }^{\circ} \mathrm{C}$ & $5 \mathrm{sec}$ \\
\hline Low lube oil pressure, engine inlet & PT201 & $350 \mathrm{kPa}$ & $5 \mathrm{sec}$ \\
\hline Low lube oil pressure, turbocharger inlet & PT271 & $220 \mathrm{kPa}$ & $15 \mathrm{sec}$ \\
\hline High lube oil temperature, T/C outlet & TE272/282 & $120{ }^{\circ} \mathrm{C}$ & $5 \mathrm{sec}$ \\
\hline Low starting air pressure & PT301 & $1.8 \mathrm{MPa}$ & $5 \mathrm{sec}$ \\
\hline Low control air pressure & PT311 & $2.0 \mathrm{MPa}$ & $5 \mathrm{sec}$ \\
\hline Low instrument air pressure & PT312 & $500 \mathrm{kPa}$ & $3 \mathrm{sec}$ \\
\hline Low HT water temp, jacket inlet & TE401 & $50{ }^{\circ} \mathrm{C}$ & $5 \mathrm{sec}$ \\
\hline High HT water temp, jacket outlet & TE402/403 & $105{ }^{\circ} \mathrm{C}$ & $5 \mathrm{sec}$ \\
\hline Low HT water press, jacket inlet & PT401 & $200 \mathrm{kPa}$ & $5 \mathrm{sec}$ \\
\hline Low LT water press, CAC inlet & PT471 & $200 \mathrm{kPa}$ & $5 \mathrm{sec}$ \\
\hline High exh. gas temp. after cylinder & TE50\#\#A/B & $540{ }^{\circ} \mathrm{C}$ & $5 \mathrm{seC}$ \\
\hline $\begin{array}{l}\text { High exh. gas temp. deviation from } \\
\text { average }\end{array}$ & TE50\#\#A/B & $\pm 80{ }^{\circ} \mathrm{C}$ & $5 \mathrm{sec}$ \\
\hline
\end{tabular}

b. Kondisi penurunan tekanan dan suhu bahan bakar methane (abnormal condition)

Setelah dibahas dan dianalisis sesuai dengan data yang ada, maka pada bagian ini akan 
dijelaskan bagaimana perbandingan antara kondisi yang normal dan tidak normal, dan dimana letak kondisi yang tidak normal di dalam sistem penyuplaian bahan bakar methane yang menyebabkan terjadinya penurunan tekanan dan suhu bahan bakar methane.

Pada prinsipnya, telah penulis paparkan di dalam penjelasan bahwa pada kondisi normal sistem penyuplaian bahan bakar methane berawal dari proses evaporasi muatan yang menjadi bahan bakar methane hingga proses kerja dari sistem tersebut. Proses terjadinya penurunan tekanan dan suhu terjadi pada saat terjadinya penggunaan GCU, pada saat generator induk menggunakan gas mode (full ahead condition), dan pada saat proses pemuatan maupun proses akan meninggalkan pelabuhan.

Pada kondisi-kondisi tersebut, akan terjadi proses kenaikan tekanan pada tangki muatan dalam selang waktu tertentu. Kenaikan tekanan pada tangki muatan disebabkan terjadinya penguapan muatan akibat perbedaan suhu yang signifikan antara muatan yang baru saja dimasukkan ke dalam tangki muatan dengan suhu tangki muatan itu sendiri. Sehingga, pada kondisi tersebut masinis muatan akan menyalakan GCU guna mengurangi tekanan yang terjadi di dalam tangki muatan. Akan tetapi hal ini akan memunculkan masalah lain yaitu penurunan tekanan dan suhu bahan bakar methane yang disebabkan terpecahnya penyuplaian bahan bakar methane yang menuju generator induk dan GCU. Masalah ini ditunjukan pada indikator yang ada pada ruang GVU. Normalnya suhu minimal untuk bahan bakar methane adalah $35^{\circ} \mathrm{C}$ dan tekanan minimal $420 \mathrm{kPa}$. Pada gambar dibawah ini, kita dapat melihat munculnya masalah berupa penurunan tekanan bahan bakar methane yang berkisar pada $370 \mathrm{kPa}$.

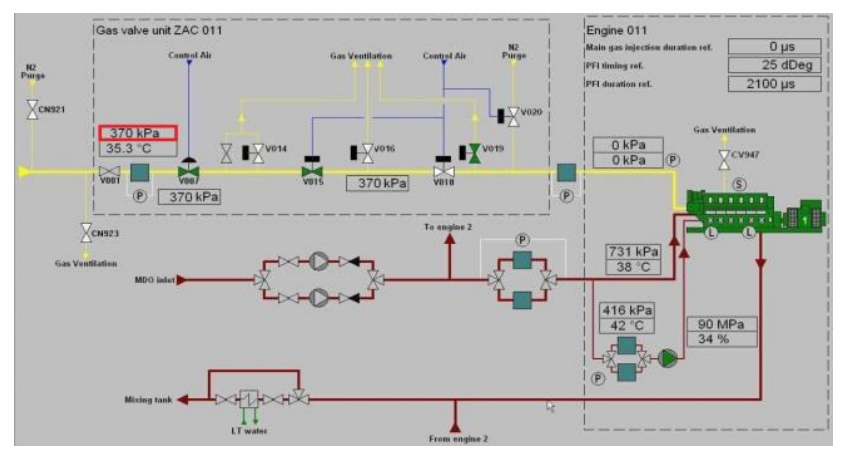

Gambar 2. Kondisi Penurunan Tekanan Bahan Bakar Methane pada GVU

\begin{tabular}{|c|c|c|c|}
\hline I) & & & H. \\
\hline \multicolumn{4}{|c|}{ Genset 1 measurements, engine serial PAAE029811 } \\
\hline \multirow{2}{*}{\begin{tabular}{|l} 
Generator load \\
Max available pawer \\
\end{tabular}} & \multirow{2}{*}{$\begin{array}{c}2202 \mathrm{~kW} \\
100 \%\end{array}$} & Main gas press & $19 \mathrm{kPa}$ \\
\hline & & Main gas press control & $50 \mathrm{kPa}$ \\
\hline \multirow{7}{*}{\begin{tabular}{|l|} 
Engine speed \\
Engine speed, MCM700 \\
Engine speed reference \\
TCA speed \\
TCB speed \\
Engine load feedback \\
Engine load, ppt \\
Max available power \\
\end{tabular}} & \multirow{7}{*}{$\begin{array}{l}511 \mathrm{ppm} \\
513 \mathrm{rpm} \\
549 \mathrm{ppm} \\
8620 \mathrm{pmm} \\
8580 \mathrm{pmm} \\
2347 \mathrm{~kW} \\
205 \% \\
100 \%\end{array}$} & Main gas press deviation from ref & $31 \mathrm{kPa}$ \\
\hline & & \begin{tabular}{|l} 
Main yas resuluator pressulue \\
MFI global gas duration ref
\end{tabular} & $\begin{array}{c}53 \mathrm{kPa} \\
0 \mu \mathrm{ss}\end{array}$ \\
\hline & & Găs valve unit, inlet gas pressure, $\mathrm{P} 03$ & $0 \mathrm{kPa}$ \\
\hline & & Gas valve unit, inlet gas temperature, T01 & $34^{\circ} \mathrm{C}$ \\
\hline & & Gas valve unit, main gas pressure, P06 & $0 \mathrm{kPa}$ \\
\hline & & F0 press, engine inlet & $704 \mathrm{kPa}$ \\
\hline & & Fo temp, engine inlet & $37^{\circ} \mathrm{C}$ \\
\hline \multirow{7}{*}{\begin{tabular}{|l|} 
Main bearing 00 temp \\
Main learing 01 temp \\
Main learing 02 temp \\
Main learing 03 temp \\
Main learing 04 temp \\
Main leaing 05 temp \\
Main learing 06 temp \\
Main learing 07 temp \\
\end{tabular}} & \multirow{7}{*}{$\begin{array}{l}71^{\circ} \mathrm{C} \\
66{ }^{\circ} \mathrm{C} \\
69^{\circ} \mathrm{C} \\
71{ }^{\circ} \mathrm{C} \\
71^{\circ} \mathrm{C} \\
71^{\circ} \mathrm{C} \\
71^{\circ} \mathrm{C} \\
66{ }^{\circ} \mathrm{C}\end{array}$} & \begin{tabular}{|l} 
Pilot fuel press, inlet \\
Pilot fuel temp, inlet
\end{tabular} & $\begin{aligned} 718 \mathrm{kPa} & \\
38^{\circ} \mathrm{C} & \end{aligned}$ \\
\hline & & \begin{tabular}{|l} 
Pilot fuel temp, inlet \\
Pilot fuel press, pump outlet
\end{tabular} & $89.6 \mathrm{MP}$ \\
\hline & & Pilot Fo press control & $32 \%$ \\
\hline & & Fuel lack control & 10700 is \\
\hline & & PFI global gas timing ref & $25 \mathrm{dDe}$ \\
\hline & & PFI global gas duration ref & 3900 ㄴ \\
\hline & & HT water press, jacket inlet & $389 \mathrm{kPa}$ \\
\hline Crankcase press & $2 \mathrm{~Pa}$ & $\begin{array}{l}\text { HT water temp, jacket inlet } \\
\text { HT water temp, jacket outlet A-lank }\end{array}$ & $\begin{array}{l}65^{\circ} \mathrm{C} \\
67^{\circ} \mathrm{C}\end{array}$ \\
\hline Air temp, TC inlet & $36{ }^{\circ} \mathrm{C}$ & HT water temp, jacket outlet B-bank & $67^{\circ} \mathrm{C}$ \\
\hline Exh WG & $0 \%$ & HT water temp, HT CAC outlet & $67^{\circ} \mathrm{C}$ \\
\hline CA press, engine inlet & $20 \mathrm{kPa}$ & HT water temp engine outlet & $66{ }^{\circ} \mathrm{C}$ \\
\hline CA temp, engine inlet & $41^{\circ} \mathrm{C}$ & HT temp controller, actual setpoint & $91{ }^{\circ} \mathrm{C}$ \\
\hline
\end{tabular}

Gambar 3. Kondisi Penurunan Suhu dan Tekanan

Bahan Bakar Methan

Masalah tersebut juga memiliki penyebab lain, yaitu kurang optimalnya penggunaan Gas Heater yang berfungsi untuk menaikan suhu dari bahan bakar methane. Normalnya, Gas Heater akan bekerja secara otomatis setelah menerima sinyal dari Gas Management System (GMS). Namun karena terjadinya kerusakan pada sistem kontrol, Gas Heater harus dinyalakan secara manual. Kurangnya familiarisasi masinis muatan terhadap penggunaan permesinan muatan ditemukan. Selain itu, pada saat Gas Heater hendak dinyalakan, ditemukan kebocoran uap pada bagian expansion bellow. Hal ini dapat mengakibatkan tidak berfungsinya Gas Heater dalam menaikkan suhu bahan bakar methane. Masalah-masalah diatas dapat terjadi secara berurutan sehingga menyebabkan terjadinya penurunan suhu dan tekanan bahan bakar methane secara drastis sehingga dapat mengakibatkan trip condition pada generator induk.

Beberapa alternatif pemecahan masalah sesuai dengan masalah diatas yaitu:

1. Tingginya Suhu Gas Buang Tiap Silinder Pada Generator Induk

a. Penggantian bagian-bagian Gas Admission Valve ataupun unit Gas Admission Valve itu sendiri secara menyeluruh.

Pada dasarnya proses kerja dari GAV adalah aktuator yang menerima electric signal dari CCM, yang kemudian dari aktuator akan membuka ataupun menutup sesuai dengan sinyal yang dikirim dari sistem kontrol yang telah diintegrasikan pada GAV itu sendiri. Terjadinya keterlambatan penerimaan dan respon pembukaan dari controller GAV tersebut dapat disebabkan kondisi bagian-bagian GAV yang sudah tidak bekerja secara maksimal, sehingga dilakukan 
penggantian beberapa bagian dalam GAV tersebut, termasuk O-ring yang sangat penting dalam hal menjaga kekedapan udara. Namun pada saat terjadinya kerusakan pada filter, penggantian secara menyeluruh harus dilakukan. Hal ini dikarenakan, filter pada GAV telah terintegrasi dan tidak dapat dilepas.

b. Melakukan pengontrolan inlet valve GCU pada saat kondisi kapal full ahead.

Permasalahan yang penulis bahas dalam penelitian ini terjadi pada saat kapal keluar dari pelabuhan dalam kondisi full ahead. Pada saat kondisi full ahead terjadi kenaikan tekanan tangki muatan, terutama pada bagian gas dome sehingga berpengaruh sistem bahan bakar methane. GCU akan secara otomatis menyala, sehingga menyebabkan penurunan suplai bahan bakar methane terhadap generator induk. Masinis muatan yang bertanggung jawab sebagai operator dari GCU harus melakukan pengendalian terhadap inlet valve dari GCU. Sehingga suplai bahan bakar methane untuk generator induk pun tidak terganggu.

2. Rendahnya Suhu dan Tekanan Bahan Bakar

Methane pada Area Kamar Mesin

a. Penggantian Cylinder Control Module

Pada alternatif pemecahan ini dilakukan suatu penggantian pada sistem kontrol, dengan cara melakukan penggantian Cyclinder Control Module (CCM) yang bertugas untuk mendeteksi parameter mesin yang akan diproses oleh Main Control Module (MCM) yang akan memberikan sinyal pengatur pembukaan dan penutupan Gas Admission Valve (GAV). Penggantian CCM dilakukan dengan mengganti modul yang lama dengan modul yang baru.

b. Melakukan pengendalian Low Duty Compressor untuk memperbesar kapasitas penyuplaian bahan bakar methane.

Permasalahan yang terjadi adalah kurangnya jumlah gas methane yang akan disuplai ke generator induk pada saat GCU menyala. Karena itu, masinis muatan sebagai operator dari LD Compressor harus memperbesar kapasitas output dari mesin tersebut, demi menghindari turunnya tekanan dan suhu bahan bakar methane di area kamar mesin. Masinis muatan harus memperbesar bukaan katup pemasukan pada LD compressor serta merubah LD compressor ke high mode dengan cara mengaktifkan coil kedua.

Pada bagian evaluasi alternatif pemecahan masalah, akan di evaluasi setiap alternatif yang penulis anggap sebagai suatu alternatif pemecahan masalah. Evaluasi akan penulis lakukan dipandang dari segi kelemahan dan kekuatan, kekurangan dan kelebihan, kerugian dan keuntungan untuk memudahkan pengambilan keputusan dalam memilih pemecahan masalah yang tepat.

1. Tingginya Suhu Gas Buang Tiap Silinder Pada Generator Induk

a. Penggantian bagian-bagian Gas Admission Valve ataupun unit Gas Admission Valve itu sendiri secara menyeluruh.

Penggantian gas admission valve secara menyeluruh aataupun bagian-bagiannya adalah salah satu alternatif pemecahan masalah yang dapat dilakukan terhadap masalah yang penulis alami. Hal ini dikarenakan permasalahan yang terjadi adalah tingginya suhu gas buang dari generator induk sebagai akibat dari buruknya pemasukan bahan bakar methane di dalam ruang pembakaran yang dilakukan oleh GAV.

Penggantian bagian GAV dapat membantu mengatasi terlalu besar dan kecilnya pembukaan GAV. Namun jika terjadi kerusakan pada bagian filternya, GAV harus diganti secara menyeluruh. Hal ini disebabkan karena filter pada GAV terintegrasi. Filter pada GAV sangatlah penting karena memiliki fungsi untuk menyaring kotoran dan karbon yang terkandung pada bahan bakar methane, akan tetapi filter pada GAV pada normalnya sangat rentan. Hal ini menyebabkan penggantian GAV secara menyeluruh selalu dilakukan karena setiap dilakukannya penggantian, filter akan selalu rusak.

Keuntungan dari alternatif pemecahan masalah ini adalah tingkat keberhasilan dalam menyelesaikan masalah tingginya suhu gas buang yang hampir $90 \%$. Karena utamanya diakibatkan oleh tidak sesuainya bukaan Gas Admission Valve (GAV) dengan sinyal yang dikirim oleh MCM, saat penggantian telah dilakukan, bukaan GAV akan sesuai dan suhu gas buang akan turun ke tingkat yag normal.

Kerugian dari alternatif pemecahan masalah ini adalah biaya yang cukup besar dalam pengantian GAV karena bagian ini memiliki harga yang cukup mahal.

b. Melakukan pengontrolan inlet valve GCU pada saat kondisi kapal full ahead.

Pada saat kapal sedang dalam kondisi full ahead dan meninggalkan pelabuhan usai proses muat di LNG terminal, akan terjadi kenaikan tekanan yang signifikan pada tangki muatan. Hal ini akan mengakibatkan GCU akan menyala secara otomatis sebagai tindakan perlindungan terhadap tekanan berlebih pada tangki muatan. Berkurangnya suplai bahan bakar methane terhadap generator induk harus dihindari, oleh karena itu salah satu alternatif pemecahan masalah adalah melakukan pengontrolan terhadap inlet valve GCU. Inlet valve tersebut dapat dikendalikan secara pneumatik melalui Cargo 
Control Console. Masinis muatan juga harus menyesuaikannya dengan kondisi suplai bahan bakar methane terhadap generator induk.

Kelebihan dari alternatif pemecahan masalah ini adalah tanpa menggunakan biaya sedikitpun, hanya memerlukan ketelitian dan kesabaran dalam proses pengontrolan dalam hal penyesuaian inlet valve GCU dengan menjaga kondisi suplai bahan bakar methane terhadap generator induk.

Kerugian dari alternatif pemecahan masalah ini adalah tidak adanya jaminan waktu bahwa masalah akan dapat segera diselesaikan, hanya bergantung kepada keahlian masinis muatan.

2. Rendahnya Suhu dan Tekanan Bahan Bakar

Methane pada Area Kamar Mesin

a. Penggantian Cylinder Control Module (CCM)

Penggantian Cylinder Control Module (CCM) adalah salah satu alternatif pemecahan masalah yang dapat dilakukan. Sistem bahan bakar generator induk yang modern bergantung pada modul elektroniknya. Modul kontrol pendeteksi parameter dan pengirim sinyal memegang peran penting dikarenakan sinyal yang dikirimkan oleh modul tersebut memengaruhi komponen mesin yang lain.

Kelebihan dari alternatif pemecahan masalah ini adalah tingkat keberhasilan penyelesaian masalah yang tinggi. Hal ini dikarenakan Cylinder Control Module (CCM) yang baru memiliki kemampuan yang baik untuk mendeteksi kondisi silinder generator induk.

Kekurangan dari alternative pemecahan masalah ini adalah mahalnya biaya yang dikeluarkan. Hal ini disebabkan oleh mahalnya komponen elektronink sistem bahan bakar generator induk.

b. Melakukan pengendalian Low Duty

Compressor untuk memperbesar kapasitas penyuplaian bahan bakar methane.

Salah satu alternatif pemecahan masalah yaitu dengan cara memperbesar kapasitas penyuplaian bahan bakar methane. Cara ini dilakukan dengan mengubah Low Duty Compressor ke high mode serta memperbesar pembukaan Variable Diffuser Vane (VDV). Pada cara ini memerlukan kewaspadaan dan ketelitian yang tinggi dari masinis muatan selaku operator permesinan muatan, hal ini disebabkan apabila pembukaan VDV terlalu besar, kemungkinan ledakan bahan bakar methane di dalam Low Duty Compressor dapat terjadi.

Kelebihan dari alternatif pemecahan masalah ini adalah tidak diperlukan biaya sedikitpun karena murni bergantung pada kemampuan masinis muatan.

Kerugian dari alternatif pemecahan masalah ini adalah tidak adanya jaminan waktu bahwa masalah akan dapat segera diselesaikan, hanya bergantung kepada keahlian masinis muatan.

Berdasarkan evaluasi pemecahan masalah maka penulis akan memberikan suatu pemecahan masalah yang efektif untuk masalah dikaji, yaitu.

1. Tingginya Suhu Gas Buang Tiap Silinder Pada

Generator Induk

Penggantian Gas Admission Valve (GAV) adalah salah satu pemecahan masalah yang diambil dalam proses pemecahan masalah tingginya suhu gas buang pada generator induk yang dapat menyebabkan masalah serius lainnya yaitu masuknya generator induk ke mode trip condition.

Pemecahan masalah yang penulis ambil berikutnya dalam masalah ini adalah melakukan penggantian Cylinder Control Module (CCM). Pemecahan masalah ini dapat tergolong efektif karena hampir selalu dapat menyelesaikan masalah tingginya suhu gas buang pada generator induk.

2. Rendahnya Suhu dan Tekanan Bahan Bakar Methane pada Area Kamar Mesin

Untuk masalah rendahnya suhu dan tekanan bahan bakar methane, penulis mendeskripsikan pengendalian kapasitas Low Duty Compressor adalah penyelesaian masalah terbaik. Karena selain dapat menyelesaikan masalah rendahnya suhu dan tekanan bahan bakar methane, optimalisasi kondisi bahan bakar methane juga dapat terlaksana. Karena dengan menggunakan pemecahan masalah ini, tingkat evaporasi, suhu, serta tekanan dari LNG di dalam tangki muatan juga dapat dikendalikan. Adapun alasan penulis mengambil pemecahan masalah tersebut dikarenakan pemecahan masalah inilah yang dilakukan oleh masinis pada saat penulis melakukan penelitian di atas MV. Tangguh Hiri.

\section{KESIMPULAN}

Kelancaran operasional dari generator induk tidak terlepas dari dukungan komponen yang terdapat di dalam sistem yang terkait pada sistem bahan bakar generator induk itu sendiri. Dimulai dari proses pemuatan LNG, pengolahan dan pengubahan LNG menjadi bahan bakar methane, serta proses penyuplaiannya ke dalam kamar mesin. Berdasarkan uraian bab-bab sebelumnya, maka dapat ditarik kesimpulan sebagai berikut:

1. Penyebab tingginya suhu gas buang pada saat generator induk menggunakan methane sebagai bahan bakar utama

Terjadinya kenaikan suhu gas buang pada generator induk disebabkan oleh beberapa faktor yang disebabkan oleh faktor internal didalam sistem itu sendiri, salah satu terjadinya adalah karena adanya kerusakan bagian-bagian pada 
generator induk yang bertugas untuk mengolah bahan bakar methane sebelum masuk ke dalam ruang pembakaran, contohnya Gas Admission Valve, dan juga Cylinder Control Module. Penyebab kerusakan pada GAV adalah terlalu tingginya suhu gas buang yang dapat mencapai $\left.500^{\circ}-550^{\circ} \mathrm{C}.\right\urcorner$ Hal ini disebabkan oleh sifat kimiawi dari methane itu sendiri.

Selain itu kerusakan pada Cylinder Control Module disebabkan karena tidak stabilnya listrik kapal sehingga sering terjadi keterlambatan pengiriman data spesifik tentang generator induk oleh Cylinder Control Module, serta rendahnya kualitas media penghantar listrik dalam hal ini kabel.

Pada saat terjadinya kenaikan suhu gas buang akan mengakibatkan terjadinya trip pada generator induk. Hal ini disebabkan relay module pada generator induk mendeteksi adanya ketidaknormalan yang bersifat membahayakan generator induk, sehingga module tersebut akan memastikan tidak adanya kerusakan lebih parah pada generator induk. Kondisi ini akan menyebabkan kapasitas listrik di atas kapal akan menurun, sehingga system propulsi akan terganggu, dan lebih parahnya lagi, dapat terjadinya black out.

2. Penyebab dari penurunan suhu dan tekanan gas methane pada saat memasuki ruang unit gas

Rendahnya suhu dan tekanan bahan bakar methane juga disebabkan oleh beberapa faktor yang disebabkan system penyuplaian methane ke kamar mesin ataupun proses penyimpanan muatan di dalam tangki muatan. Salah satu contoh terjadinya adalah tidak maksimalnya penggunaan Low Duty Compressor yang yang bertugas untuk menyuplai dan menekan methane sebelum masuk ke dalam sistem bahan bakar methane di dalam kamar mesin. Hal ini disebabkan kurangnya pengetahuan dan pengalaman masinis muatan selaku operator permesinan tersebut.

Selain kurangnya pengoptimalan Low Duty Compressor, masalah ini juga memiliki penyebab lain, yaitu kurang optimalnya penggunaan Gas Heater yang berfungsi untuk menaikan suhu dari bahan bakar methane. Gas Heater pada normalnya harus dipasang pada posisi auto, akan tetapi disebabkan terjadinya masalah pada pengiriman signal yang dilakukan oleh Gas Management System. Gas Heater tidak dapat melakukan pengaturan suhu secara sempurna. Selain itu, ditemukan kebocoran uap pada bagian expansion bellow. Hal ini mengakibatkan berkurangnya tekanan media pemanas di dalam heater. Sehingga uap yang bertugas untuk menaikkan panas kepada bahan bakar methane tidak dapat melakukan tugasnya secara maksimal.
Berdasarkan hasil penelitian yang penulis simpulkan, dalam hal pencegahan dan penanganan terlalu tingginya suhu gas buang pada generator induk dan juga rendahnya tekanan dan suhu bahan bakar methane yang akan masuk ke kamar mesin maka penulis memiliki saran sebagai berikut :

1. Untuk menghindari terlalu tingginya suhu gas buang generator induk pada saat generator induk menggunakan methane sebagai bahan bakarnya yaitu dengan cara melakukan penambahan suplai udara ke dalam ruang pembakaran yaitu dengan mengatur bukaan waste gate sehingga suplai udara dari turbocharger akan maksimal dan kurangnya rasio udara pembakaran yang menyebabkan tingginya suhu gas buang dapat dihindari.

2. Untuk masalah rendahnya suhu dan tekanan bahan bakar methane, penulis memberikan saran bahwa untuk menghindari terjadinya masalah tersebut, perlunya familiarisasi mendalam tentang permesinan muatan kepada masinis muatan. Sehingga masinis muatan dapat memiliki inisiatif tertentu pada saat proses pengendalian muatan sehingga akan terhindar dari masalah ini pada waktu yang berikutnya.

\section{DAFTAR PUSTAKA}

[1] Akademi Ilmu Pelayaran. 1976. Motor-Motor Diesel Kapal AIP. Jakarta.

[2] Arismunandar, Wiranto dan Tsuda, Koichi. 1975. Motor Diesel Putaran Tinggi. Jakarta: PT. Pranadya Paramita

[3] Atmaja, Suyatna B. 1990. Metodologi Penelitian Sosial. Bandung : FIP FKIP.

[4] Balai pustaka. 1994. Kamus Besar Bahasa Indonesia. Balai pustaka, Jakarta

[5] Daryus, A. 2008. Manajemen Pemeliharaan Mesin. Jakarta.

[6] Harahap, Nurdin. 2007. Mesin Penggerak Utama. Jakarta: Seaman Corp Technical Division, STIP

[7] Heizer, Jay., Render, Berry. 2001. Operation Management.

[8] Maanen, P. Van. (n.d). Motor Diesel Kapal Jilid 1. Nautech. Jakarta 
[9] Marleev, V.L. 1995. Operasi Dan Pemeliharaan Mesin Diesel. PT. Gelora Aksara Pratama. Jakarta.

[10] Morton, Thomas D. 1975. Reed' Motor Engineering Knowledge For Marine Engineer. Grand Books \& Records CO. Taiwan

[11] NSOS. 1985. Manajemen Perawatan dan Perbaikan. Jakarta.

[12] Rabiman dan Arifin, Zainal. 2011. Sistem Bahan Bakar Motor Diesel. Yogyakarta.

[13] Salim, Abbas. 2006. Manajemen Transportasi. Raja Grafindo, Jakarta.

[14] Sehwarat, M.S dan Narang, J.S. 2001. Production Management.

[15] Sukoco dan Arifin, Zainal. 2008. Teknologi Motor Diesel. Alfabeta. Bandung.

[16] Tamin, Ofyar Z. 2000. Perencanaan dan Permodelan Transportasi. Bandung: Institut Teknologi Bandung.

[17] Undang- Undang RI No. 17 Tahun 2008 Tentang Pelayaran. 